\title{
UNDERSTANDING ONLINE FOOD ORDERING: HOW THE PROCESS RESULTS IN SATISFACTION OF THE CUSTOMERS
}

\section{Zehra Dilistan SHIPMAN ${ }^{1}$}

\begin{abstract}
The purpose of this study is to understand which factors affect customer satisfaction as well as future behavioral intention in online food ordering. A conceptual model was developed to assess the effect of factors on customer satisfaction. The dimensions of online service quality are identified through existing literature. The study employed a quantitative research design collecting data via convenience sampling. Data were analyzed by regression model to test the proposed hypotheses. The results show that website quality, delivery, and food quality explain the satisfaction of customers for online food ordering, which, in turn positively affects future behavioral intentions.
\end{abstract}

Keywords: online food ordering, online service quality, customer satisfaction

JEL Classification: M31, Y80, L66

\section{ONLINE GIDA SIPARIŞîiNI ANLAMAK: MÜŞTERI MEMNUNIYETINDE SÜREÇ NASIL SONUÇLANIR \\ $\ddot{O} z$}

$\mathrm{Bu}$ çalışmanın amacı online yemek siparişinde müşteri memnuniyeti ve davranışsal niyetlerini etkileyen faktörleri incelemektir. Bu amaçla belirlenen faktörlerin etkisini araştırmak üzere kavramsal bir araştırma modeli oluşturulmuş ve söz konusu faktörler literatürdeki mevcut çalışmalar doğrultusunda belirlenmiştir. Çalışmada nicel araştırma yöntemi izlenilmiş ve önerilen hipotezlerin test edilmesinde regresyon analizi kullanılmıştır. Analiz sonuçları, web sitesi, yemek kalitesi ve teslimat faktörlerinin müşteri memnuniyetini ve gelecekteki davranışsal niyetlerini pozitif yönde etkilediğini doğrulamıştır.

Anahtar Kelimeler: online yemek siparişi, online hizmet kalitesi, müşteri memnuniyeti

JEL Sinıflaması: M31, Y80, L66

\section{Introduction}

Online food ordering has been increasing steadily during the recent years. Especially with the continuous developments in technology, food delivery service has transformed from ordering via phone to digital ordering to satisfy the demands of customers. That is, online services create new opportunities for food industry to reach more customers. However, the success of the businesses mostly depends on the online service quality provided to the customers (Zeithaml, 2002). As a result, both professionals and academicians have started to focus on how to improve online service quality to satisfy the customers as well as to affect their future behavioral intentions.

To survive in online retailing services, the companies need to understand all factors affecting online service quality at each encounter that take place before, during and after transactions (Zeithaml, 2002).

1 Dr. Öğretim Üyesi, İstanbul Bilgi Üniveristesi, Turizm ve Otelcilik Y.O., Gastronomi ve Mutfak Sanatları, dilistan.shipman@ bilgi.edu.tr ORCID: 0000-0001-9829-960X 
Basically, service quality is customers' overall evaluation to assess the service (Lewis \& Booms, 1983). However, there is no clear measurement of the dimensions of service quality since it depends on both the interpretations of the customers and the industry.

On the other hand, for the e-service quality, it is mainly about the quality of the web site and the quality of the service offerings (Santos, 2003; Zeithaml, Parasuraman, \& Malhotra, 2000).

Service quality is especially important for companies because it does not only increase customer satisfaction but it also positively influences customers' future behaviors Cronin \& Taylor, 1992). More specifically, customer satisfaction is all about meeting customers' expectations through service performance and satisfied customers are more likely to repurchase if the service performance meets their expectations (Syed \& Norjaya, 2010). Hence, it is important to understand the performance factors affecting the satisfaction as well as behavioral intention of customers. Unfortunately, even there are previous studies analyzing the service quality dimensions in traditional food services, a limited number of research has tried to explore the factors affecting service quality for online food ordering.

Thus, to expand the knowledge about online food ordering services, this study mainly focuses on understanding the factors affecting customers' satisfaction with online food ordering and how satisfaction affects their behavioral intentions. As a result, the specific objectives of this study are to:

- Understand the factors affecting the perceived quality of online food ordering;

- Analyze the relationship between online food ordering service quality dimensions and customer satisfaction;

- To assess the relationship between customers' satisfaction with online food ordering and their future behavioral intentions.

For these purposes, this paper first discusses the current literature, followed by research methods, analysis and results, and conclusion.

\section{Review of literature}

\subsection{E-service quality for online food ordering}

According to Boyer, Hallowell, and Roth (2002, p. 175), e-services can be defined as: "all interactive services that are delivered on the internet using advanced telecommunications, information, and multimedia technologies. On the other hand, e-service quality is about "the extent to which a web site facilitates efficient and effective shopping, purchasing and delivery" (Zeithaml et al., 2000, p. 11). Therefore, as it is understood from the definitions, e-services represent the services delivered via online technologies, e-service quality is about the efficiency and effectiveness of these technology.

Like many industries, the food industry has also benefited from the boom in the e-commerce. That is, the increased number of food delivery applications and websites has changed the dynamics of the food industry by making food available on online platforms. Basically, ordering food via a web page or mobile application is called online food ordering. The process includes searching for restaurant or different cuisine types, choosing for a delivery location and the form of payment. Thus, as noted by Cox and Dale (2001), traditional service quality dimensions are not applicable to online retailing.

Accordingly, recent studies have tried to identify the dimensions of online service quality. 
For instance, in a qualitative study, Wolfinbarger and Gilly (2002) have come up with four factors, namely the Web site design, reliability, privacy/security, and customer service.

In a similar vein, another study has proposed convenience/accuracy, feedback/complaint management, efficiency, queue management, accessibility, and customization as the underlying dimensions for online retailing.

Similarly, when online service quality is analysed from the point of online food ordering, recent research has also explored similar factors affecting the service quality for online ordering platforms. Specifically, one of the most important factors affecting how customers perceive the quality of e-services is the website. That is, design of the website, particularly the navigation capability and visual appeal determine the quality of website (Cyr, 2008), which, in turn affect perceived quality and customer satisfaction (Lee \& Lin, 2005). The reason why website design is so important is customers are self-served. In other terms, they perform most of the function on their own (Jun, Yang, \& Kim, 2004). Thus, a well-designed website needs to be user-friendly enabling customers to navigate smoothly (Rice, 1997; Wigand, 1997). However, even website quality is crucial for online users, information quality, namely the information provided on the website, has been also identifies as one of the critical dimensions affecting the perceived quality of customers. That is the website should provide accurate and reliable information. As suggested by Kateranttanakul (2002), reliable websites lower the perceived risk for customers and help them during their decision process. Similarly, Daft and Lengel (1986) have also contemned that quality, accuracy and reliability of information are prerequisites of an information exchange process. Moreover, the quality of information is not only important for perceived quality, but it also ensures satisfaction of customers as well as affects their intention to purchase online (Liu, He, Gao, \& Xie, 2008).

In addition to online system quality, which is composed of website design and information accuracy, the other important concern for online shoppers is the security. Since online purchases are directly related with the level of trust toward the website, customers expect websites to protect their personal information. Accordingly, previous studies have also supported the importance of the security issue in online shopping by focusing its role in enhancing customer satisfaction. That is, customer satisfaction has been found to increase as the level of perceived risk for security decreases (Elliot \& Fowell, 2000). Related to the issue security, customers also care about the payment. In other terms, they do not only look for convenience in terms of payment but they also be sure about the security of the payment system. Therefore, payment is also an important factor to understand how customers evaluate the quality of e-services. For the payment dimension, previous studies have suggested that customers using online ordering expect websites to provide a secure payment system protecting their personal financial data (Franzak, Pitta, \& Fritsche, 2001; Grace \& Chia-Chi, 2009).

While all the stated dimensions, which are website design, information accuracy, security, and payment, are mostly related with the online system, the product is still an important factor to evaluate the quality of a e-service. Hence, similar to traditional services, e-services also need to focus on product quality. For online food ordering, product quality is all about the quality of food that is delivered to customers. In other terms, it is related with the expected standards for the food delivered. According to literature, customers usually expect food fresh, healthy, tasty, well presented, and well-cooked (Kivela, Inbakaran, \& Reece, 1999). 
Moreover, since the food represent the tangible part of the e-service, it is especially important for the customer satisfaction.

As mentioned by previous studies, food quality is one of the most important factors to create customer satisfaction for food industry (Andaleeb \& Conway, 2006; Kivela et al., 1999).

In addition to all these dimensions, the last but not the least factor is the delivery. Delivery is "the amount of time necessary for the package to go from the distribution center to the customer's door". For e-service environment, delivery has an important role in developing customer satisfaction as well as affecting their future behavioral intentions. Especially, the timing of the delivery is the most important issue for online shoppers (Dholakia \& Zhao, 2010). Since they usually use online food ordering for time and its convenience, customers expect food to be delivered on time. Further, they also expect the right item to be delivered at the appropriate temperature and conditions.

\subsection{E-service quality, customer satisfaction, and behavioral intentions}

Customer satisfaction is about meeting the expectations of the customers as a result of the performance of products or services (Oliver, 1980). Thus, it is mainly the comparison of prepurchase expectations with the performance received. In a similar vein, for e-services, customer satisfaction is defined as "the extent to which consumers' perceptions of the online shopping experience confirm their expectations" (Li \& Zhang, 2002, p.514). That is, if the performance of online services meets or exceeds the expectations, customer would be satisfied. However, customer satisfaction is not the ultimate goal for the activities. Rather, it is the antecedent of establishing long-term customer relationships. As it is suggested by Byambaa \& Chang (2012), satisfied customers are more likely to have repurchase intention, create positive word-of-mouth, and to become loyal. Therefore, it is especially important to understand which factors influence customer satisfaction in different service settings.

Specifically, for online shopping satisfaction, different studies have come up with different dimensions to explain satisfaction of customers. Of those studies, Syed and Norjaya (2010) have identified website design, reliability, product variety, and delivery performance. On the other hand, another research has end up with eight factors, which are website design, security, information quality, payment method, e-service quality, product quality, product variety, and delivery service (Guo, Ling, \& Liu, 2012). Hence, it can be concluded that previous studies have different results for the factors explaining satisfaction. As a result, reviewing different research results, this study has adopted website quality, information quality, security, payment, food quality, and delivery as the dimesons of e-service quality that influence satisfaction in online food ordering (Kedah, Ismail, Haque, \& Ahmed, 2015). However, previous research also suggests that not every dimension has the same influence on perceived service quality or customer satisfaction (Jun et al., 2014). Therefore, the issue is not only to identify the relevant dimensions, but it is also important to assess the relative importance of each dimension. As a result, to answer the questions of what is the relative importance each factor on customer satisfaction and how customer satisfaction affects behavioural intentions of customers for online food ordering, this research has developed the following hypotheses and the conceptual research model;

H1: Website design has a positive effect on customer satisfaction.

$\mathrm{H} 2$ : Information quality has a positive effect on customer satisfaction. 
H3: Security has a positive effect on customer satisfaction.

H4: Payment has a positive effect on customer satisfaction.

H5: Food quality has a positive effect on customer satisfaction.

H6: Delivery has a positive effect on customer satisfaction.

H7: Customer satisfaction has a positive influence on behavioural intentions of customers.

Figure 1. Conceptual research model of the study

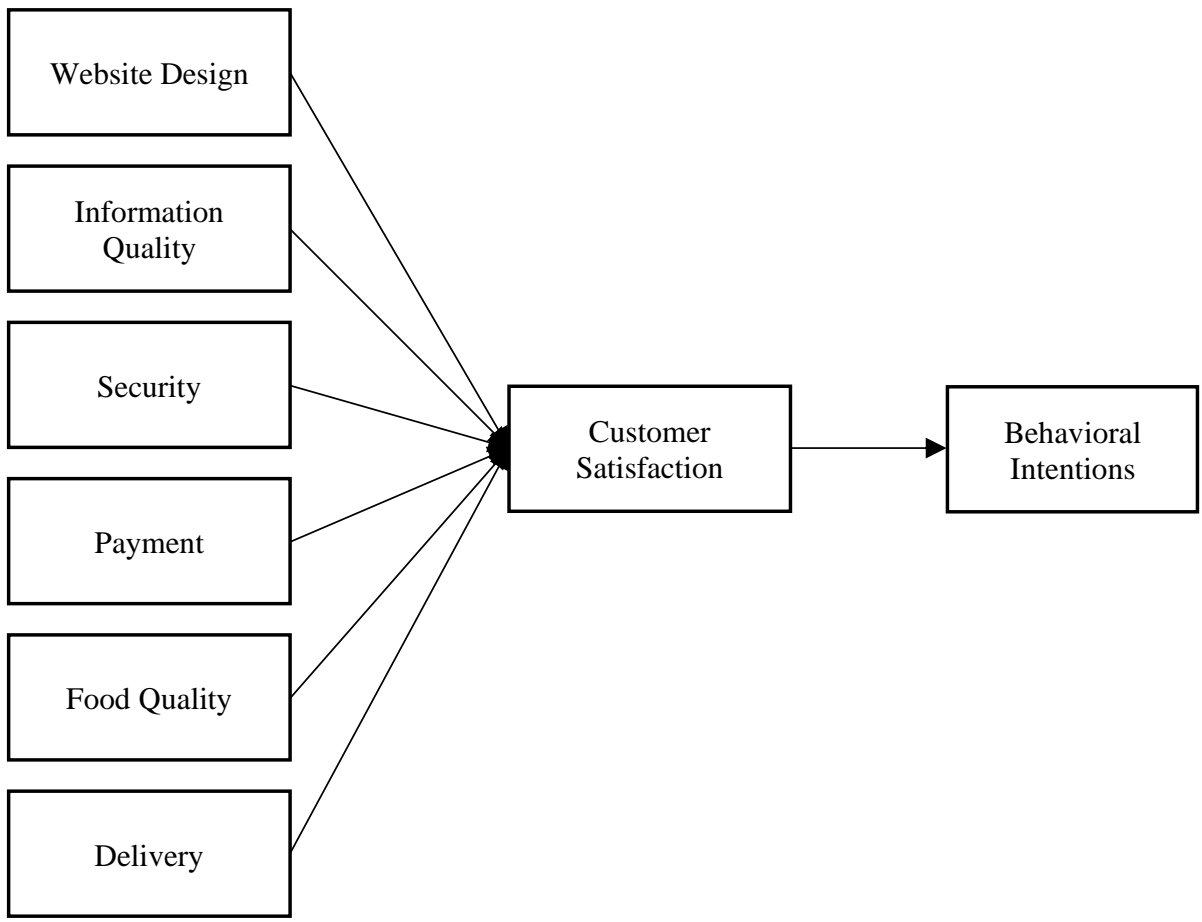

3. Methods

The data for the study were collected from the customers who have been used online food ordering websites before. A structured questionnaire was used to collect data and respondents are selected via convenience sampling. After data collection process, 213 usable surveys are identified for further data analysis.

The survey item is consisted of four different parts. While the first part included questions regarding the service quality dimensions identified from previous literature, the second and the third part included questions about customer satisfaction and behavioral intentions. Lastly, the forth part consisted of demographic questions regarding age, gender, marital status, and education level of customers. Respondents were asked to rate their perceptions and opinions for e-service quality dimensions, satisfaction, and their future behavioral intentions.

The measurement items for online food ordering were adopted from previous studies. 
That is, while dimensions for information quality and website quality were developed by Jeong, Oh, and Gregoire (2003) as well as by Muylle, Moenaert, and Despontin (2004), delivery and payment were borrowed from Wolfinbargerhe and Gilly (2003). Lastly, security and food quality items were adopted from the study of Liu, He, Gao, and Xie (2008).

Lastly, to analyze the data, the study first used descriptive statistics for the frequency analysis of demographic variables. On the other hand, to assess the relationship between service quality dimensions and customer satisfaction as well as behavioral intentions, this research used regression analysis.

\section{Results}

The study first used descriptive statistics to analyze the demographic profile of the respondents. The results are provided in table 1. Mainly, among the 210 survey participants, males represented $60.5 \%$ and females represented $39.5 \%$ of the sample. Of those respondents, $21 \%$ was married and $79 \%$ was single. While the majority of the participants were between the ages of $18-25(62.9 \%)$, the rest of the sample consisted of customers above 25 . Lastly, for the education level, university degree holders represented $68.9 \%$ of the research sample.

Table 1. Demographic profile of respondents

\begin{tabular}{llll}
\hline Variable & & $\mathbf{N}$ & $\mathbf{\%}$ \\
\hline Gender & Male & 83 & 60.5 \\
& Female & 127 & 39.5 \\
Age & Total & 210 & 100 \\
& $18-25$ & 132 & 62.9 \\
& $26-35$ & 31 & 14.8 \\
& $36-45$ & 17 & 8.1 \\
Marital Status & T6 or above & 30 & 14.3 \\
& Total & 210 & 100 \\
Education Level & Single & 166 & 21 \\
& Married & 44 & 79 \\
& Total & 210 & 100 \\
& High School & 9 & 4.2 \\
& Pre-College & 24 & 11.3 \\
& Bachelor & 146 & 68.9 \\
& Graduate & 33 & 15.6 \\
& Total & 210 & 100 \\
\hline
\end{tabular}

Besides demographic profile, the descriptive analysis further used to get the mean scores for the measurement items and underlying factors (see Table 2).

After descriptive statistics, factor analysis was performed to better assess the factors and their underlying measures. As the preliminary analysis, this research first performed the KaiserMeyer-Olkin measure of sampling adequacy and Bartlett's test of sphericity. For the data the value of Kaiser-Meyer-Olkin measure of sampling adequacy was found to be .863 , which is between the recommended accepted values. Moreover, a significant result of Bartlett's test with a value of less than .05 also confirmed that there is not a redundancy between factors.

As a result, at the end, principal factor analysis using VARIMAX rotation was used to analyse the underlying factors of online food ordering. The study retained the factors that have eigenvalues exceeding one. Moreover, regarding the cut-off value of factor loadings, commonly used cut-off point of .40 was used to determine the significant attributes (Hair, Black, Babin, Anderson, \& Tathum, 2006). 
At the end, from 26 six items identified from previous literature, 23 of them were kept resulting in six factors. The attributes and underlying factors are provided in Table 2.

Table 2. Measurement items for online food ordering and underlying factors

\begin{tabular}{|c|c|c|c|c|}
\hline Measurement Items & Mean & $\begin{array}{l}\text { Factor } \\
\text { Loading }\end{array}$ & $\begin{array}{l}\text { Eigen } \\
\text { Value } \\
\end{array}$ & $\begin{array}{c}\text { Cronbach } \\
\text { Alpha }\end{array}$ \\
\hline Information Quality & & & 3.59 & .665 \\
\hline $\begin{array}{l}\text { Website provides accurate information to } \\
\text { potential customers }\end{array}$ & 3.50 & .524 & & \\
\hline $\begin{array}{l}\text { The information provided on the website is } \\
\text { easily understandable }\end{array}$ & 3.48 & .497 & & \\
\hline I can find all detailed information I need & 3.25 & .465 & & \\
\hline Website Quality & & & 3.02 & .843 \\
\hline The information on the website is well organized & 3.91 & .483 & & \\
\hline The website is visually appealing & 3.49 & 609 & & \\
\hline I found it easy to move around the web site & 3.41 & .501 & & \\
\hline The website is user-friendly & 3.86 & .670 & & \\
\hline Security & & & 2.39 & .731 \\
\hline I feel secure giving out credit card information & 3.47 & .547 & & \\
\hline The website has adequate security features & 3.48 & .525 & & \\
\hline I feel secure in may transactions & 3.47 & .651 & & \\
\hline I feel like my privacy is protected & 3.24 & .680 & & \\
\hline Payment & & & 2.10 & .812 \\
\hline $\begin{array}{l}\text { The website provides me with the payment } \\
\text { options according to my preferences }\end{array}$ & 3.86 & .473 & & \\
\hline $\begin{array}{l}\text { The website provides efficient payment gateway } \\
\text { system }\end{array}$ & 3.92 & .679 & & \\
\hline I accept payment option provided by the website & 3.81 & .708 & & \\
\hline Delivery & & & 2.05 & .761 \\
\hline The product comes as represented by the website & 3.07 & .652 & & \\
\hline The product is delivered by the time promised & 3.37 & .602 & & \\
\hline You get what you ordered from the website & 3.60 & .496 & & \\
\hline The food sent by the website is well packaged & 3.40 & .501 & & \\
\hline $\begin{array}{l}\text { Delivery riders are efficient in delivering the } \\
\text { foods }\end{array}$ & 3.50 & .616 & & \\
\hline Food Quality & & & 1.78 & .792 \\
\hline The foods delivered are fresh & 3.45 & .554 & & \\
\hline The foods are well presented & 3.54 & .756 & & \\
\hline The foods delivered are well cooked & 3.07 & 629 & & \\
\hline Food operators provide a variety of food items & 3.12 & .557 & & \\
\hline
\end{tabular}

Lastly, the study performed regression analysis to test the hypothesized relationship between online food ordering factors and customer satisfaction as well as the relation between satisfaction and behavioral intentions. The regression model is found to explain the $55.2 \%$ of the variance for customer satisfaction at a significance level of $p<.00$. The model summary for regression analysis is provided in Table 3 below.

\begin{tabular}{ccccc}
\hline \multicolumn{5}{c}{ Table 3. Regression Model Summary } \\
\hline $\mathbf{R}$ & R Square & Adjusted R Square & $\mathbf{F}$ & Sig. \\
.743 & .552 & .538 & 40,242 & .000 \\
\hline
\end{tabular}

Lastly, the standardized coefficients and test of the hypotheses are also provided in Table 4. As it could be understood from the table, of the six factors identified for online food ordering, only three of them were found to significantly affect customer satisfaction. Specifically, website design, delivery, and food quality positively increase the satisfaction of the customers. On the other hand, this research could not find a significant influence of information quality, payment, and security on customer satisfaction. Moreover, this study also evidenced the positive effect of satisfaction on future behavioral intentions of customers. 
Table 4. Results of regression analysis

\begin{tabular}{lllll}
\hline Path to & Path from & Ho $_{\mathbf{0}}$ & Std. Coeff. & t-value \\
\hline Customer Satisfaction & Information Quality & H1: Not Supported & .026 & .419 \\
& Website Design & H2: Supported & .410 & $6.200^{*}$ \\
& Security & H3: Not Supported & .003 & .048 \\
& Payment & H4: Not Supported & .085 & 1.677 \\
& Delivery & H5: Supported & .253 & $3.274^{*}$ \\
& Food Quality & H6: Supported & .167 & $2.552^{*}$ \\
\hline Behavioral Intentions & Customer Satisfaction & H7: Supported & .764 & $4.004^{*}$
\end{tabular}

Note. $\mathrm{p}^{*<.05}$

That is, as customers are satisfied with online food ordering services, they are more likely to repeat their purchases as well as recommend the service to other people.

\section{Conclusion and Discussion}

The increased popularity of online food ordering in recent years has made it crucial to understand how e-service process affects customers' satisfaction as well as their intentions about online ordering. Therefore, the purpose of this study was to understand how online food ordering process satisfy the needs of customers and how this satisfaction affect their future behavioral intentions. In order to answer these questions, this research has first identified the relevant factors for e-service quality in food ordering through a review of existing literature. As a result, the study came up with six dimensions, namely the website quality, information quality, security, payment, delivery, and food quality. After identifying these factors, the effect of all these dimensions were analyzed to assess their influence on customer satisfaction, which, in turn, affects future behaviors.

The results have showed that even six e-service quality dimension were offered to explain the satisfaction, the study has evidenced a significant effect of only three of them. Specifically, website quality, delivery, and food quality showed a significant positive effect on satisfaction. On the other hand, for the proposed relation between satisfaction and future behavioral intentions, satisfaction was found to positively influence repurchase behaviors as well as intention to recommend online food ordering. Considering these findings, this study has implications both theoretically and practically.

From the theoretical perspective, even previous studies have proposed six factors, which are information quality, website quality, security, payment, delivery, and food quality (Cyr, 2008; Christian \& France, 2005; Christy \& Matthew, 2005; Daft \& Lengel; 1986; Grace \& Chia-Chi, 2009), this research found only three of them explain the satisfaction of customers. In other terms, website quality, delivery, and food quality were the only factors explaining satisfaction in online food ordering process.

This contradictory result could be explained by the role of trust in e-commerce environment. As suggested by Yoon (2002), website trust has a significant influence on satisfaction of customers. That is, security, payment, and information quality dimensions could be related to customers' trust toward the website. In other terms, trust might be acting as an antecedent of satisfaction for online food ordering services. Similarly, specifically for the food ordering, Kedah at al. (2005) found that these three factors positively enhance the trust of customers for the website, which, in turn, explain the customer satisfaction in online ordering. 
Besides its theoretical implication, the results of the research also have practical implications for the industry. First of all, online services need to distinguish between system quality and service quality. While information quality, security, payment, and website design are related with system quality, delivery and food are related with service quality (Kedah et al., 2005). Therefore, the online food services need to concentrate on system quality to increase the trust of customers. As the results suggest, trust might be the antecedent to create satisfaction in online services. On the other hand, service quality is still an important consideration as it is for traditional services. That is, online food companies should focus on delivery and food quality to increase their sales because these factors directly enhance the satisfaction and result in repurchase behaviors. In other terms, in online food ordering, customers expect timely delivery of the food in good conditions. Accordingly, in addition to good service both for delivery and food, customers also expect website to be user friendly and easy to navigate when searching for different alternatives. Therefore, it can be concluded that website design, delivery, and food itself are considered to be the most important factors to ensure satisfaction. In contrary, payment, security, and information quality might be the factors supporting the satisfaction process through creating trust in online services.

\section{References}

Boyer, K. K., Hallowell, R., \& Roth, A. V. (2002). E-services: operating strategy - a case study and a method for analyzing operational benefits. Journal of Operations management, 20(2), 175-188.

Byambaa, B., \& Chang, K. (2012). The influence of factors of online purchase on customer satisfaction in Mongolian Airlines. International Proceedings of Economics Development and Research, 57(15), 80-85.

Cox, J., \& Dale, B. G. (2001). Service quality and e-commerce: an exploratory analysis. Managing Service Quality: An International Journal, 11(2), 121-131.

Cronin Jr, J. J., \& Taylor, S. A. (1992). Measuring service quality: a reexamination and extension. Journal of marketing, 56(3), 55-68.

Cyr, D. (2008). Modeling web site design across cultures: relationships to trust, satisfaction, and e-loyalty. Journal of Management Information Systems, 24(4), 47-72.

Daft, R. L., \& Lengel, R. H. (1986). Organizational information requirements, media richness and structural design. Management science, 32(5), 554-571.

Dholakia, R. R., \& Zhao, M. (2010). Effects of online store attributes on customer satisfaction and repurchase intentions. International Journal of Retail \& Distribution Management, 38(7), 482-496.

Elliot, S., \& Fowell, S. (2000). Expectations versus reality: a snapshot of consumer experiences with Internet retailing. International journal of information management, 20(5), 323336.

Franzak, F., Pitta, D., \& Fritsche, S. (2001). Online relationships and the consumer's right to privacy. Journal of Consumer Marketing, 18(7), 631-642.

Grace, T. R. (2009). Chia-Chi sun. Dimensions and influencing factors of customer loyalty in the intermittent service industry. Online Information Review, 33(3), 458-475.

Guo, X., Ling, K. C., \& Liu, M. (2012). Evaluating factors influencing consumer satisfaction towards online shopping in China. Asian Social Science, 8(13), 40.

Hair Jr JF, Black WC, Babin BJ, Anderson R, Tathum R. (2006). Multivariate data analysis. 6th ed. Upper Saddle River: Prentice Hall.

Jeong, M., Oh, H., \& Gregoire, M. (2003). Conceptualizing web site quality and its consequences in the lodging industry. International Journal of Hospitality Management, 22(2), 161-175.

Jun, M., Yang, Z., \& Kim, D. (2004). Customers' perceptions of online retailing service quality and their satisfaction. International Journal of Quality \& Reliability Management, 21(8), 817-840. 
Katerattanakul, P. (2002). Framework of effective web site design for business-to-consumer internet commerce. INFOR: Information Systems and Operational Research, 40(1), 57-70.

Kedah, Z., Ismail, Y., Haque, A. A., \& Ahmed, S. (2015). Key success factors of online food ordering services: An empirical study. Malaysia Management Review, 50(2), 19-36.

Kivela, J., Inbakaran, R., \& Reece, J. (1999). Consumer research in the restaurant environment, Part 1: A conceptual model of dining satisfaction and return patronage. International Journal of Contemporary Hospitality Management, 11(5), 205-222.

Lee, G. G., \& Lin, H. F. (2005). Customer perceptions of e-service quality in online shopping. International Journal of Retail \& Distribution Management, 33(2), 161176.

Lewis, R. C., \& Booms, B. H. (1983). The marketing aspects of service quality. Emerging perspectives on services marketing, 65(4), 99-107.

Li, N., \& Zhang, P. (2002). Consumer online shopping attitudes and behavior: An assessment of research. AMCIS 2002 Proceedings, 74.

Liu, X., He, M., Gao, F., \& Xie, P. (2008). An empirical study of online shopping customer satisfaction in China: a holistic perspective. International Journal of Retail \& Distribution Management, 36(11), 919-940.

Muylle, S., Moenaert, R., \& Despontin, M. (2004). The conceptualization and empirical validation of web site user satisfaction. Information \& management, 41(5), 543-560.

Oliver, R. L. (1980). A cognitive model of the antecedents and consequences of satisfaction decisions. Journal of marketing research, 17(4), 460-469.

Rice, M. (1997). What makes users revisit a Web site? Marketing News, 31(6), 12.

Saad Andaleeb, S., \& Conway, C. (2006). Customer satisfaction in the restaurant industry: an examination of the transaction-specific model. Journal of services marketing, 20(1), 3 11.

Santos, J. (2003). E-service quality: a model of virtual service quality dimensions. Managing Service Quality: An International Journal, 13(3), 233-246.

Syed, S. A., \& Norjaya, M. H. (2010). What factors influence online brand trust: evidence from online tickets buyers in Malaysia. Journal of theoretical and applied electronic commerce research, 5(3), 78-89.

Wigand, R. T. (1997). Electronic commerce: Definition, theory, and context. The information society, 13(1), 1-16.

Wolfinbarger, M., \& Gilly, M. (2002). . comQ: dimensionalizing, measuring, and predicting quality of the e-tail experience. Marketing Science Institute Report, (02-100).

Wolfinbarger, M., \& Gilly, M. C. (2003). eTailQ: dimensionalizing, measuring and predicting etail quality. Journal of retailing, 79(3), 183-198.

Yoon, S. J. (2002). The antecedents and consequences of trust in online-purchase decisions. Journal of interactive marketing, 16(2), 47-63.

Zeithaml, V. A. (2002). Service excellence in electronic channels. Managing Service Quality: An International Journal, 12(3), 135-139.

Zeithaml, V. A., Parasuraman, A., \& Malhotra, A. (2000). A conceptual framework for understanding e-service quality: implications for future research and managerial practice. Marketing Science Institute. 